ポピュラーサイエンス

……........................

手垢は語る………か

副 島 啓 義

(株)島津製作所 $\mathbf{T} 604$ 京都市中京区西ノ京桑原町 1 (1988 年 12 月 26 日 受理)

\section{Finger Grime Talks about a Person, Doesn't it?}

Hiroyoshi SOEZIMA

Shimadzu Corporation

1, Nishinokyo-Kuwabaracho, Nakagyo-ku, Kyoto 604

(Received December 26, 1988)

\section{1.はじめに}

“てのインキ(スタンプ台と同様のあの) を指につけて 下さい。側面にあ先の方にあつけて。そうしたらての紙 のこの場所に押して下さい。指をてろがすようにして， ずれないように腹面あ側面む先の方あ。はい, では次の 指す。右手がすんだら左手む。”とうやって 10 本の指全 部のほぼ完全な指紋が公式台帳に記録された。多分その 後コンピュータメモリにインプットされたであろう。 3〜4 年前のことだったか自宅にドロボウに入られたて とがあった。警察が来てひととおり状況調査をして，侵 入場所と思われるあたりの指紋を採取したようであっ た。その後家族の指紋との照合が必要とかで事実上強制 的に全員の 10 指の指紋をバッチリ記録していった。

どうもドロボウをつかまえるととより家族（国民）の 指紋を集めることの方に熱心であったように思えてなら ない。なおドロボウの方がどうなったかは警察からは何 の連絡もないままで終わってしまった。

指紋が個人を特定するのに重要な情報源であるととは いうまでもない。指紋はその形状（いわゆるうず巻とか 流れなど）により 9 種に分類され 1〜9 の数字があては められている。また，指紋なしというのああっててれは 数字 0である。乙の数字により，5指に示中環小拇（法 医学などの分野では 5 指をこう呼ぶらしい）の順で 5 桁 の番号をつける。さらに左手を分子, 右手を分母にして $00000 \sim \frac{99999}{00000}$ と表示し, これにより 100 億人分の登録 ができる。別の人の指紋が 1 本であ同じになる確率は 1/640 億といわれている。さらに指紋の部分であって あ, 細部の 12 あるいはそれ以上の項目の特徵による分 類が行われており，乙の場合 12 項目全てが一致する確
率は $1 / 204$ 兆 8000 億となるそうである。

さて，以上は指紋を“形”として見ているわけである が，指紋をその “成分”の立場から見るとどうであろう か。実際に指紋としてあちてちに付いているのは, (1)指 先からの分泌物之古くなって脱落する皮膚細胞，(2)身体 の他の部分に触れたときのその部分の分泌物（たとえば 鼻の油), (3)身体につけている各種の化粧品, (4)石けん・ 洗凬，(5)ちこちの物に触ったときにその物の表面付着 物や場合によってはその物自体が指先に移ったもの，な どなどのゴチャ混ぜになったすのつまり“手垢”であ る。乙の手垢はある個人の身体的特に新陳代謝の状況と 生活状況を物語っているはずである。付いた手垢は相当 に薄い。かなり微量な成分あ含まれる。また手垢を付け られた物との相互作用ああるであろう。これらの状態は 表面科学の世界と重なるところが多いように思われる。

少々野次馬的興味から指紋として付く手垢を調べてみ る。

\section{2. 手垢の成分}

\section{1 身体および身体からの分泌物}

人の身体の元素組成が 表 $1^{11}$ に示されている。C, O, $\mathrm{H}$ および $\mathrm{N}$ は当然多い。 $\mathrm{P}, \mathrm{Ca}$ あ当然かなりあり, $\mathrm{S}$ が案外多い。次いで $\mathrm{Na}, \mathrm{K}, \mathrm{Cl}$, それと $\mathrm{Mg}$ である。 $\mathrm{Si}$ が思いの外少ない。微量元素として $\mathrm{Mn}, \mathrm{Fe}, \mathrm{Cu}$, $\mathrm{Zn}$ ，さらに B，Coといったものが含まれる。

\subsection{1 皮膚および皮膚の脂質生成}

図 $1^{2)}$ は表皮細胞が生まれて，日が経ち角質化し， 脱落していく過程を示している。また, 各段階における 成分の変化む示されている。脱落するときすなわち手垢 となるときは, 脂肪酸, 中性脂肪, コレステロールが増 加しており，グルコースやリン脂質が減っている。図 $2^{3)}$ は皮膚から分必される脂質の様子を示している。グ リセロールはグリセリンのととである。とのグリセリン は脂肪中の脂肪酸とエステル化してグリセリドとなる。 一部の脂肪酸はグリセリンと結びつかずに遊離脂肪酸と なって分必する。とてろでてれらの脂質の分泌量と性別 年齢との関係を 表 $2^{3)}$ に示す。いわゆる中年の分泌量は 若い年齢層に比べて多くはない。“あぶらぎってテカテ カした中年の肌”というのはどこからくるのであろう か。皮膚の形状の違い一一年の皮膚がマクロ的には皺 があってもミクロ的にはつっぱっているので，脂質が皮 膜となって光ってみえる——らなのか, 角質細胞の含 脂質量が若年層より多いのか, 表皮細胞の新陳代謝が低 下しているため角質細胞が多く存在し，そのため脂質が 多いのか，その他の理由なのか筆者は知らない。 
表 1 人体の元素組成 ${ }^{1)}$ 。

\begin{tabular}{|c|c|c|}
\hline 元素 単位 & 相対原子数 ${ }^{a)}$ & 欄内各単位 $/ \mathrm{kg}^{\dagger, \mathrm{b}}$ \\
\hline $\mathrm{H}$ & 9200 & - \\
\hline $\mathrm{C}$ & 1620 & - \\
\hline $\mathrm{N}$ & 370 & $34 \mathrm{~g}$ \\
\hline $\mathrm{O}$ & 3900 & - \\
\hline $\mathrm{Na}$ & 11.3 & 80 meq \\
\hline $\mathrm{Mg}$ & 1.65 & $0.47 \mathrm{~g}$ \\
\hline $\mathrm{Si}$ & 0.14 & - \\
\hline $\mathrm{P}$ & 20.3 & $12.0 \mathrm{~g}$ \\
\hline $\mathrm{S}$ & 20 & - \\
\hline $\mathrm{Cl}$ & 5 & $50 \mathrm{meq}$ \\
\hline $\mathrm{K}$ & 5.6 & $69 \mathrm{meq}$ \\
\hline $\mathrm{Ca}$ & 34.4 & $22.4 \mathrm{~g}$ \\
\hline $\mathrm{Mn}$ & 0.002 & - \\
\hline $\mathrm{Fe}$ & 0.09 & $74 \mathrm{mg}$ \\
\hline $\mathrm{Cu}$ & 0.0063 & $1.7 \mathrm{mg}$ \\
\hline $\mathrm{Zn}$ & 0.038 & $28 \mathrm{mg}$ \\
\hline B & - & $0.37 \mathrm{mg}$ \\
\hline Co & - & $0.22 \mathrm{mg}$ \\
\hline
\end{tabular}

$\dagger$ 脂肪を除く.

a) "Biophysical Chemistry", Vol. 1, ed. by J. T. Edsall and J. Wyman (Academic Press, New York, 1957) p. 4.

b) "Scientific Tables", 7 th Ed., ed. by K. Dien and C. Lentner (Ciba-Geigy, Basle, 1973) p. 517.

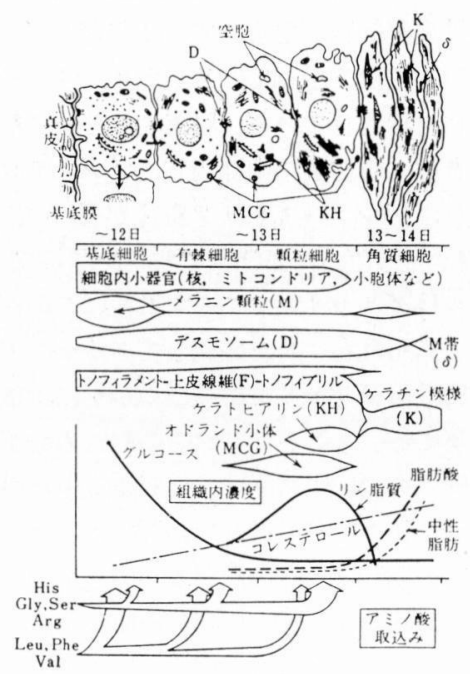

図 1 表皮細胞の増殖と老化 ${ }^{2)}$ 。

\subsection{2 汗}

汗は大半が水分であるが身体に存在するほとんぞ全て の無機成分を含み, 多種の含窒素化合物やビタミン類を

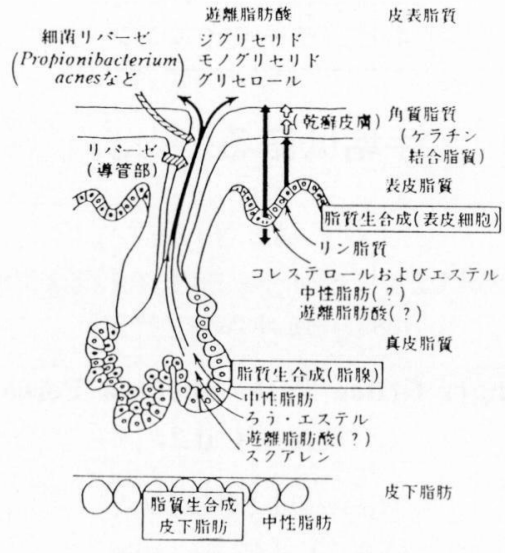

図 2 皮虞脂質の生成 ${ }^{3)}$ 。

表 2 皮虞脂質分泌量 ${ }^{3)}$ 。

\begin{tabular}{r|rr|rr}
\hline 年 齢 & \multicolumn{1}{|c|}{ 子男 } & \multicolumn{2}{|c}{ 女 } \\
\hline $20-29$ & $2.45 \pm 0.93(61)$ & \multicolumn{2}{|c}{$1.88 \pm 0.90(50)$} \\
$30-39$ & $2.49 \pm 0.89(50)$ & \multicolumn{2}{|l}{$1.84 \pm 0.87(26)$} \\
$40-49$ & $2.21 \pm 0.99(29)$ & \multicolumn{2}{|l}{$1.83 \pm 1.09(30)$} \\
$50-69$ & 2.39 & $(22)$ & 0.96 & $(17)$ \\
$70-90$ & 1.69 & $(13)$ & 0.89 & $(11)$ \\
\hline
\end{tabular}

$\mathrm{mg}$ 脂質 $/ 10 \mathrm{~cm}^{2} / 3 \mathrm{hr}$. 平均値士標準偏差. ( ) 中は 例数.

a ）大城戸宗男：代謝 11，1023（1974）。

b ）篊野倫, 大城戸宗男: “皮慮病態生化学”, 谷奥 喜平, 岩下健三, 竹内勝編（医学書院，1970） p. 371 ; 佐藤良夫: 同, p. 410; 猪股成美: 同, p. 457.

c) P. E. Pochi and J.S. Strauss: "Advances in Biology of Skin", Vol. 6, ed. by W. Montagna (Pergamon Press, 1965) p. 122.

含んでいる。ただ，脂質は脇の下などにあるアポクリン 腺からの汗には含まれるが, 普通の汗——エクリン腺か らの汗一には含まれていない。あっとも先に述べた皮 膚から分泌される脂質であるグリセリンは水分に完全に 溶解するので, 結果として汗とあぶらは混ったものとし て体表に存在する。汗はその成分も発汗量屯外温・体温, 体調, 運動状態, 発汗部位などによって変化する。多く の人の報告によりまとめられた無機成分の含量が表 $3^{4}$ に示されている。この表でピロカルピン発汗とあるの は, 副交感神経末端を刺激するピロカルピンという薬物 により発汗をうながして調べたものである。

\section{2 化粧品}

世の中が豊かで，まがりなりにも平和であることと， 化粧品の種類や使用量は多分正の相関があるのであろ う。大変な種類之量の化粧品が使われている。生化学的 
表 3 汗の無機成分 ${ }^{4)}$ 。

\begin{tabular}{|c|c|c|c|}
\hline 無 機 成 分 & 含 & 単 位 & 考 \\
\hline 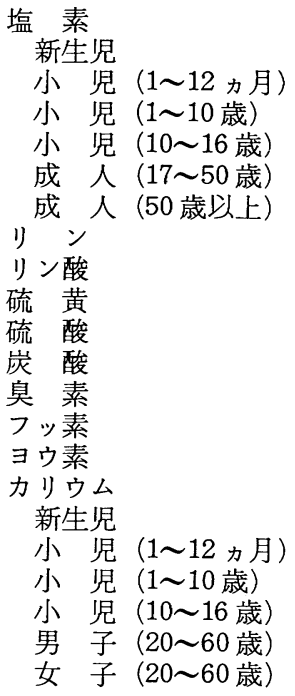 & $\begin{array}{l}14 \sim 64^{\mathrm{a})} \\
2.5 \sim 22.1^{\mathrm{b})} \\
0 \sim 31.5^{\mathrm{b})} \\
1.5 \sim 38.3^{\mathrm{b})} \\
0 \sim 65.1^{\mathrm{b})} \\
34.3 \sim 43.5^{\mathrm{c})} \\
0.09 \sim 0.43^{\mathrm{d})} \\
\left.10 \sim 17^{\mathrm{e}}\right) \\
0.7 \sim 7.4^{\mathrm{f})} \\
7 \sim 190^{\mathrm{g})} \\
1.6 \sim 18.6^{\mathrm{h})} \\
0.6 \sim 0.502^{\mathrm{i})} \\
182 \sim 1.8^{\mathrm{j})} \\
0.2 \sim 12.2^{\mathrm{k})} \\
5.4 \sim 18 \\
\\
2 \sim 14^{\mathrm{a})} \\
4.4 \sim 18.0^{\mathrm{b})} \\
4.0 \sim 15.2^{\mathrm{b})} \\
3.7 \sim 13.3^{\mathrm{b})} \\
4.3 \sim 10.7^{\mathrm{l})} \\
5.8 \sim 14.2^{\mathrm{l})}\end{array}$ & $\begin{array}{c}\text { meq/l } \\
" 1 \\
" \\
" \\
" \\
\text { mg/l } \\
" \\
" \\
" \\
\text { vol\% } \\
\text { mg/l } \\
" 1 \\
\mu \mathrm{g} / l \\
\text { meq/l } \\
" \\
" \\
" \\
" \\
"\end{array}$ & 無機硫酸は 50\% 以下 \\
\hline $\begin{array}{l}\text { ナトリウム } \\
\text { 新生児 } \\
\text { 小 児 }(1 \sim 12 \text { カ月 }) \\
\text { 小 児 }(1 \sim 10 \text { 歳 }) \\
\text { 小 児 }(10 \sim 16 \text { 歳 }) \\
\text { 男 尒 }(20 \sim 60 \text { 歳 }) \\
\text { 女 }(20 \sim 60 \text { 歳 }) \\
\text { 老 }(60 \text { 歳以上 }) \\
\text { カルシウ } \\
\text { マグネシウム } \\
\text { 鉄 } \\
\text { 男 子 } \\
\text { 女 子 } \\
\text { 銅 } \\
\text { マンガン } \\
\text { 业 鈶 }\end{array}$ & $\begin{array}{l}10 \sim 62^{\mathrm{a})} \\
5.1 \sim 23.9^{\mathrm{b})} \\
3.3 \sim 35.7^{\mathrm{b})} \\
6.0 \sim 52.4^{\mathrm{b})} \\
9.7 \sim 94.1^{\mathrm{m})} \\
0 \sim 73.9^{\mathrm{m})} \\
7.5 \sim 104^{(\mathrm{l}} \\
0.2 \sim 6^{\mathrm{g})} \\
0.03 \sim 4^{\mathrm{g})}\end{array}$ & $\begin{array}{c}\text { meq/l } \\
\text { " } \\
\text { " } \\
\text { " } \\
\text { " } \\
\text { " } \\
\text { " }\end{array}$ & $\begin{array}{l}\text { ピロカルピン発汗 } \\
\text { アポクリン腺は鉄排泄の重要器官 } \\
\text { で, 摄取鉄の } 1 / 4 \text { は汗としでる }\end{array}$ \\
\hline
\end{tabular}

a) O. Stur : Oesterr. Z. Kinderheilkd. Kinderfuerosorge 6, 347 (1961).

b) H. Shwachman, et al. : Pediatrics 32, 85 (1963).

c) P. R. de Haller, P. Siegenthaler, A. Hampai, A. Spahr, V. Vulliet and R. Favre : Schweiz. Med. Wochenschr. 92, 1493 (1962).

d) H. H. Mitchell and T.S. Hamilton : J. Biol. Chem. 178, 345 (1949).

e) J. T. Clarke, E. Elian and H. Shwachman: Am. J. Dis. Child. 101, 490 (1961).

f) G. A. Talbert, et al.: Am. J. Physiol. 106, 488 (1933).

g) I. L. Schwartz: "Mineral Metabolism", Vol. 1, Part 1 A, ed. by C. L. Comar and F. Bronner (Academic Press, New York, 1960) p. 346.

h) S. Itoh: "Essential Problems in Climatic Physiology", ed. by H. Yoshimura, et al. (Nankodo, 1960) p. 3.

i) T. Cornbleet: J. Invest. Dermatol. 1, 399 (1938).

j) McClure, et al.: J. Ind. Hyg. 27, 159 (1945).

k) H. Spector, H. H. Mitchell and T. S. Hamilton: J. Biol. Chem. 161, 137 (1945).

1) T. McKendrick: Lancet 1, 183 (1962).

m) C. C. Lobeck and D. Huebner: Pediatrics 30, 172 (1962).

n) R. Hussain, et al.: Indian J. Med. Res. 48, 235 (1960).

o) R. Hussain and V. N. Patwardhan: Lancet 1, 1073 (1959).

p) A. S. Prasad, A. R. Schulert, H. H. Sandstead, A. Miale, Jr. and Z. Farid: J. Lab. Clin. Med. 62, 84 (1963). 
に生理的に実に理にかなったあのから，どう見てあ“仮 面”としかいいようのない使われ方がされているあのま で色々である。化粧とはよくぞ化けると書きしかなとい った感がする。なお，石けん・洗剂は身体用のものは化 粧品とみなされており，したがってシャンプや歯みがき あ化粧品である。

化粧品に使用されている種々の物質（原料）は 1500 程が公式に（厚生大臣認定品とか日本化粧品工業連合会 による）知られているが，実際には 2000 種はあるとい うことである。この数字には香料は含まれていないとの ことで, 香料のように現在の分析技術では検出し得ない 極微量成分を含んでいるであろう物質まで考えると，化 粧品の材料はさらにずっと多いと思われる。これらをて てで全て記すのは現実的ではないので, よく使われてい る代表的化粧品について簡単に記述するのにとどめる。 あし実際に手垢成分から化粧品を推定するとしたら, 相 当量のデータベースからの検索が必要であろう。

\section{[基礎化粧品］}

いわゆるクリームや乳液, 化粧水の類である。目的・ 効果, 水性・油性の度合, 粘性の度合などにより多くの 種類がある。洗浄性・保湿性・栄養性の成分および香料 や防腐剂などにより構成される。たとえば，ステアリン 酸, ワセリン, 流動パラフィン, ポリオキシエチレンモ ノオレイン酸エステル，ポリエチレングリコール，エチ ルアルコール, トリエタノールアミン, スルホ石炭酸亜 鉛などである。

\section{[メイクアップ化粧品］}

“化ける”ための直接用具がてれである。白粉（白くな いあの屯ある。ファンデーションなど), 口紅, マニキ ユア, マスカラ, アイライナー, まゆ墨, アイシャドウ などである。用途がら無機成分・顔料が多い。たとえ ば, タルク, 炭酸カルシウム, 二酸化チタン, ステアリ ン酸亜鉛, ラノリン, ヒマシ油, イソプロピルミリスチ ン酸エステルなどである。結果として生体成分でないす のがかなり含まれる。

\section{[薬用化粧品]}

日焼けを防ぐあのと，適度な日焼けを生ずるあの（サ ンタン)，防臭を目的とするあのなどである。日焼け防 止には紫外線を吸収するためにパラアミノ安息香酸誘導 体やサリチル酸誘導体などが用いられ，酸化チタンが含 まれるととあある。サンタン製品には日光紅班（皮膚の 炎症）を引き起こす 290 ３20 nm の紫外線は吸収する が, 小麦色の肌をつくるメラニン色素沈着を起とす $320 \sim 400 \mathrm{~nm}$ 領域は吸収しないような工夫がなされてい る。防臭化㛇品は体臭を防止するあのである。体臭のほ とんどは汗（特にアポクリン腺からの汗）が細菌により
分解して発生するので，皮膚を収れんして発汗を抑制す るか，殺菌剤により細菌の発育を抑えるかの物質が用い られる。収れん剂としてはアルミニウムの塩化物・硫酸 化物などが用いられている。

[毛髮用化粧品]

最近とみに製品を増やしているのが毛髪用化粧品であ り, TV コマーシャルであ毎日のように新製品が出現し ている。シャンプ・リンス, 育毛・養毛剂, 整髪料, パ ーマネントウエーブローション, 染毛剂などがある。手 垢成分に比較的なりそうなのは, 育毛・養毛剂と整髪料 であろう。前者は各社競争で研究開発が進んでおり, 皮 脂分泌抑制（塩酸ピリドキシンなど），男性ホルモン抑 制剂（ $\beta$-グリチルレチン酸など）, 新陳代謝活性剂（二 コチン酸ベンシル, パントテニールエチルエーテルな ぞ）が配合され，ラウリル硫酸塩や酢酸トコフェロール (ビタミンE) などが含まれるあのあある。後者の成分 は植物油 (ヒマシ油, オリーブ油, ツバキ油), 密ろう, 木ろう, ワセリン, パラフィンなどと香料である。

\section{[口腔用化粧品]}

歯みがき，口腔清凉剤（口臭防止を含む）などである が，変わったところでは入歯固定剤などもそうである。 歯みがきには研磨剂（炭酸カルシウム, リン酸カルシウ ム, 硫酸カルシウム, 水酸化アルミニウム, 無水ケイ酸 など), 洗浄剤（発泡剂とほぼ同じ意味, 石けん, 硫酸ド デシルナトリウム，ラウリル硫酸ナトリウムなど）が含 まれる。また，薬用成分として酢酸トコフェロール（ビ タミンE), トラネキサム酸, $\beta$-グリチルレチン酸, 塩 酸クロルヘキシジンなどを含むむのあある。

[浴用化粧品]

温泉ブームにのって浴用化粧品む增加している。主な あのは硬水軟化剤と温泉有効成分である。前者には，炭 酸ナトリウム, リン酸ナトリウムなどがあり, 後者とし ては, 二酸化炭素, 硫黄分, 鉄分, タール分などがあ る。また, 酒石酸, クエン酸, 硫酸ナトリウムなどが含 まれているあのもある。

\section{3 その他の成分}

その他というのは 2.1 節と 2.2 節以外ということなの で特定することはできない。ただ，手垢という状態から 考えると, チリ・ホコリ・䋐維くずの類, 比較的固化し にくい光沢剂, 家庭用洗剂, ガソリン・灯油・潤滑油, 殺虫剂, インキ・塗料, 食品, などなどが挙げられるの ではなかろうか。

\section{3. 分 析 例}

野次馬的興味から書いてみるといったものの, 正直い って少々絶望的な気分がしている。手垢として残された 
表 4 手垢成分の分析に供した試料。

\begin{tabular}{|c|c|c|c|c|c|}
\hline 試料 & 人 & 性別 & 年 齢 職 業 & 指紋（手垢）をつけたときの状況 & 分 析 \\
\hline A & 甲 & 女 & $\begin{array}{l}\text { 事務職 } \\
\text { ?㗤(まだまだ若い) }\end{array}$ & $\begin{array}{l}\text { 植物エキス配畣の洗顔剂で手を洗い } 10 \text { 分 } \\
\text { 他に触れ蛙過銅板に押付ける }\end{array}$ & $\begin{array}{l}\text { EPMA } \\
\text { ESCA }\end{array}$ \\
\hline B & 甲 & 女 & $\begin{array}{l}\text { 事務職 } \\
\text { ?歳（まだまだ若い) }\end{array}$ & $\begin{array}{l}\text { 一般事務を半日実施後そのまま一銅板に押 } \\
\text { 付ける }\end{array}$ & $\begin{array}{l}\text { EPMA } \\
\text { ESCA }\end{array}$ \\
\hline $\mathrm{C}$ & 乙 & 男 & $\begin{array}{l}\text { 技術(設計) } \\
20 \text { 代 }\end{array}$ & $\begin{array}{l}\text { CAD を用いた設計を半日実施後そのまま } \\
\text { ＼cjkstart銅板に押付ける }\end{array}$ & $\begin{array}{l}\text { EPMA } \\
\text { ESCA }\end{array}$ \\
\hline D & - & - & - & なにも付けていない銅板 & $\mathrm{ESCA}$ \\
\hline $\mathrm{E}$ & 丙 & 男 & $\begin{array}{l}\text { 技術（管理職） } \\
\text { 中年 }\end{array}$ & 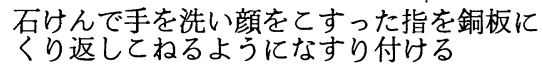 & ESCA \\
\hline $\mathrm{F}$ & 丁 & 男 & $\begin{array}{l}\text { 技術（管理職） } \\
\text { 中年 }\end{array}$ & $\begin{array}{l}\text { 整髮料をつけた髮に触った指をガラス板に } \\
\text { 押付ける }\end{array}$ & GC \\
\hline G & 丁 & 男 & $\begin{array}{l}\text { 技術（管理職） } \\
\text { 中年 }\end{array}$ & 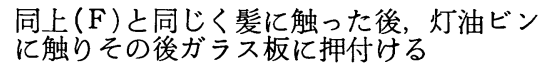 & GC \\
\hline
\end{tabular}

僅かのあのに含まれるであろう多種多様な物質を，しか あその多くは存在量 (絶対量) が非常に少ないであろう し，未知なもの（予測し難いあの）含むと思われるも のをはたして分析できるのであろうか。それに，1つの 手垢（指紋）を多種の分析法・装置で分析する必要があ るが，乙の場合ますます存在量や分析における試料破壊 や試料消失が問題になる。

とはいうあのの 2,3 試みてみた。試料は表 4 亿示 すように，純銅板に普通の力で指を押しつけた指紋 $(\mathrm{A}$, B， C), その純銅板自体 (D), ベタベタ塗りたくったも の $(\mathrm{E})$, 指紋をガラスにつけたあの (F, G) である。 EPMA により $\mathrm{A} \sim \mathrm{C}$ を, ESCA により $\mathrm{A} \sim \mathrm{E}$ を $\mathrm{GC}$ で Fと Gを分析した。

\subsection{EPMA による分析}

試料は処理なしでそのまま分析した。定性分析で得た $\mathrm{Ca}, \mathrm{K}, \mathrm{Cl}, \mathrm{S}, \mathrm{Na}, \mathrm{O}, \mathrm{N}, \mathrm{C}$ の 8 元素についてマッピ ングを行った。分析面積は $4 \mathrm{~mm} \times 4 \mathrm{~mm}$ で, 加速電圧 $15 \mathrm{kV}$, 試料電流 $0.5 \mu \mathrm{A}, 512 \times 512$ 画素で, 1 画素あ たりのサンプリング時間 $10 \mathrm{~m} \mathrm{sec}$ である。結果を各元 素ごとに 16 段階の信号強度分けでカラ一表示し, 図 3 に示す。このような試料-データを定量化するのは色々 問題があるのだが, EPMA で用いられている SEF 法 (Standard Sensitivity and Experimental Factor, 標 準感度法ともいう。標準試料を用いない簡便定量法）に より濃度換算し, 試料 A - B - Cの中で相対的に濃度が 高く, これら 8 元素の合計で重量濃度が $100 \%$ に近く なった試料Aを 100 として濃度比較して表 5 亿示す。 この表の各数字は比較的面積の多い部分の濃度を表し,

（）内の值はこのような場所ああるということを示す。 試料 B - Cの合計が 100 でないのは試料Aに比べて付着 量が少ないてとを示している。表 4 , 表 5 および図 3 を見くらべながら少し考察してみる。特徴的なととは, (1)AとBは同一人物であるが成分差がかなりある, (2) B
とCは別人であるがそれほど大きな差はない，(3濃度分 布はほとんどの元素が高濃度と低濃度に 2 極化しており 中間濃度がない。(1)は手を洗った直後は洗浄の状況がよ く表れ指紋む付きやすい，(2)は特別な物質を扱っている のでなりれば指の表面状態は似てくる，(3は指の表面の 付着層が 1 層なら，押し付ける強さにより相手側 (銅板)

表 5 EPMA 分析による相対濃度 (\%)。

\begin{tabular}{c|c|cc|cc}
\hline & \multicolumn{1}{|c|}{$\mathrm{A}$} & \multicolumn{2}{|c|}{$\mathrm{B}$} & \multicolumn{2}{|c}{$\mathrm{C}$} \\
\hline $\mathrm{Ca}$ & $0.33(6.7)$ & 0.15 & $(8.7)$ & 0.07 & $(5.3)$ \\
$\mathrm{K}$ & $50.1(0.7)$ & 0.7 & $(13.4)$ & $-(0.7,13.4)$ \\
$\mathrm{Cl}$ & $12.7(0.13)$ & $0.15(8.7)$ & 0.15 & $(7.4)$ \\
$\mathrm{S}$ & 0.07 & 0.1 & $(0.5)$ & 0.03 & \\
$\mathrm{Na}$ & $20.1(0.2)$ & 0.2 & $(14.7)$ & $-(0.2,6.0)$ \\
$\mathrm{O}$ & $12.0(0.7)$ & 1.3 & $(12.0)$ & 0.75 & $(10.7)$ \\
$\mathrm{N}$ & $2.0(6.7)$ & 0.7 & $(6.7)$ & - & $(0.7)$ \\
$\mathrm{C}$ & $2.7(33.4)$ & 2.0 & $(30.0)$ & 2.0 & \\
\hline Total & 100 & 5.3 & & 3.0 & \\
\hline
\end{tabular}

（）の数を示す場所は面積としては小さい。

への付着量に中間值がありそうだが，より表面側とより 皮膚に近い側で状態が 2 層になっているのではないか, つまり分泌物を主体とする湿った内側層と外部からの付 着物を含んだ乾いた外側層, といったととを示している。

ところで, AとBを比べと， $\mathrm{Ca} \cdot \mathrm{S} ・ \mathrm{C}$ は大差ない のに, $\mathrm{A}$ は $\mathrm{K} \cdot \mathrm{Cl} \cdot \mathrm{Na} \cdot \mathrm{O} \cdot \mathrm{N}$ が特に多い。汗・血液 中の電解成分 $(\mathrm{K}, \mathrm{Cl}, \mathrm{Na})$ や皮膚自体と皮膚脂質および 洗顔剤成分 (KやNa が含まれる) が考えられる。また $\mathrm{B}$ （甲）とC（乙）ではBの方が概して付着量が多いのは， 甲さんが女性で指先むしっとりとしているせいか。

\subsection{ESCA による分析}

試料は処理なしでそのまま分析した。まず最表面を定 性分析し, その後アルゴンでェッチングしながら深さ方 

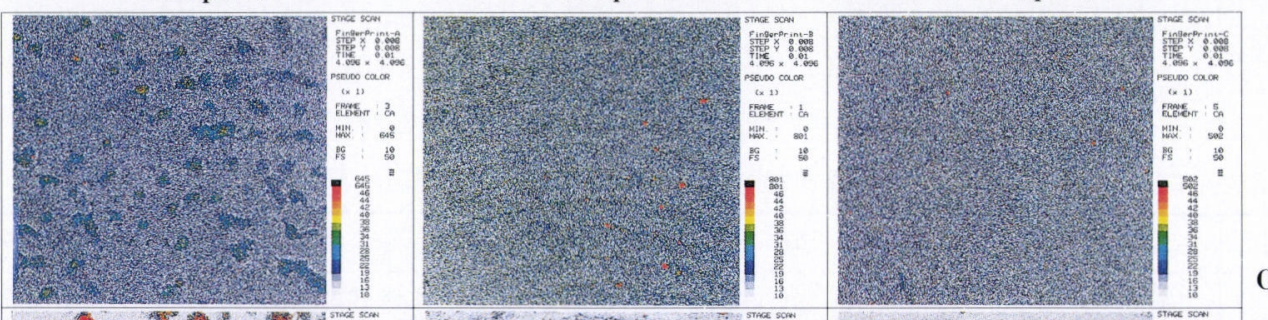

*

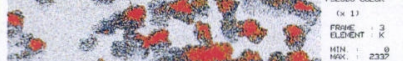

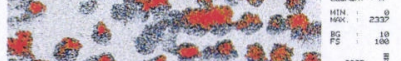

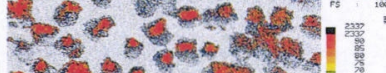

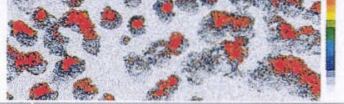

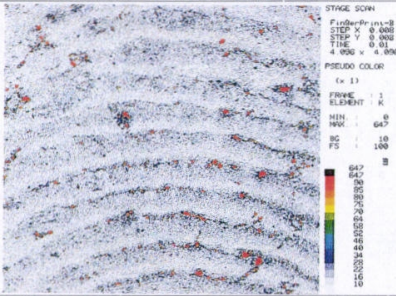

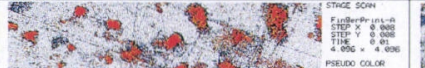

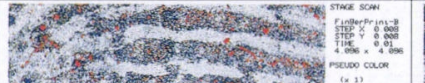

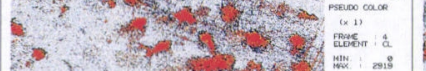

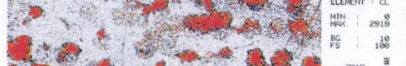

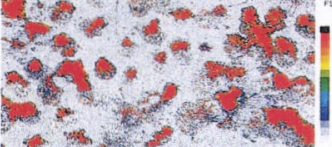
6 ond and

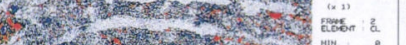

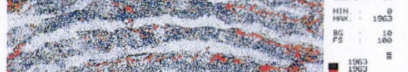

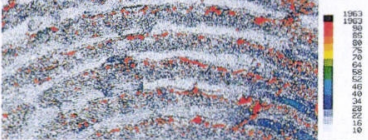

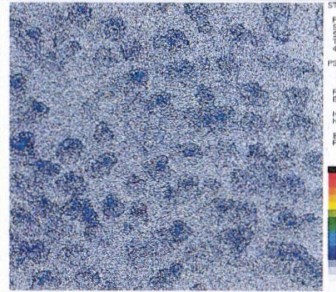

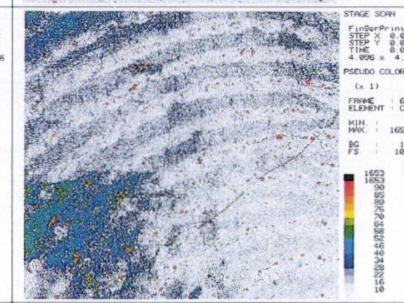

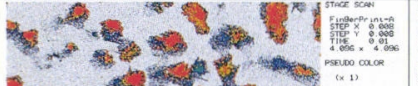

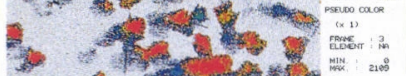

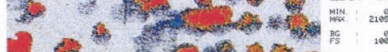

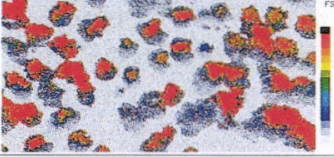
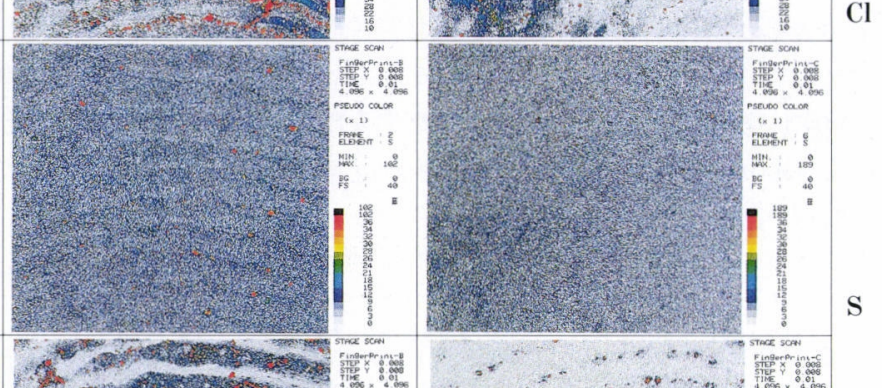

\section{8}
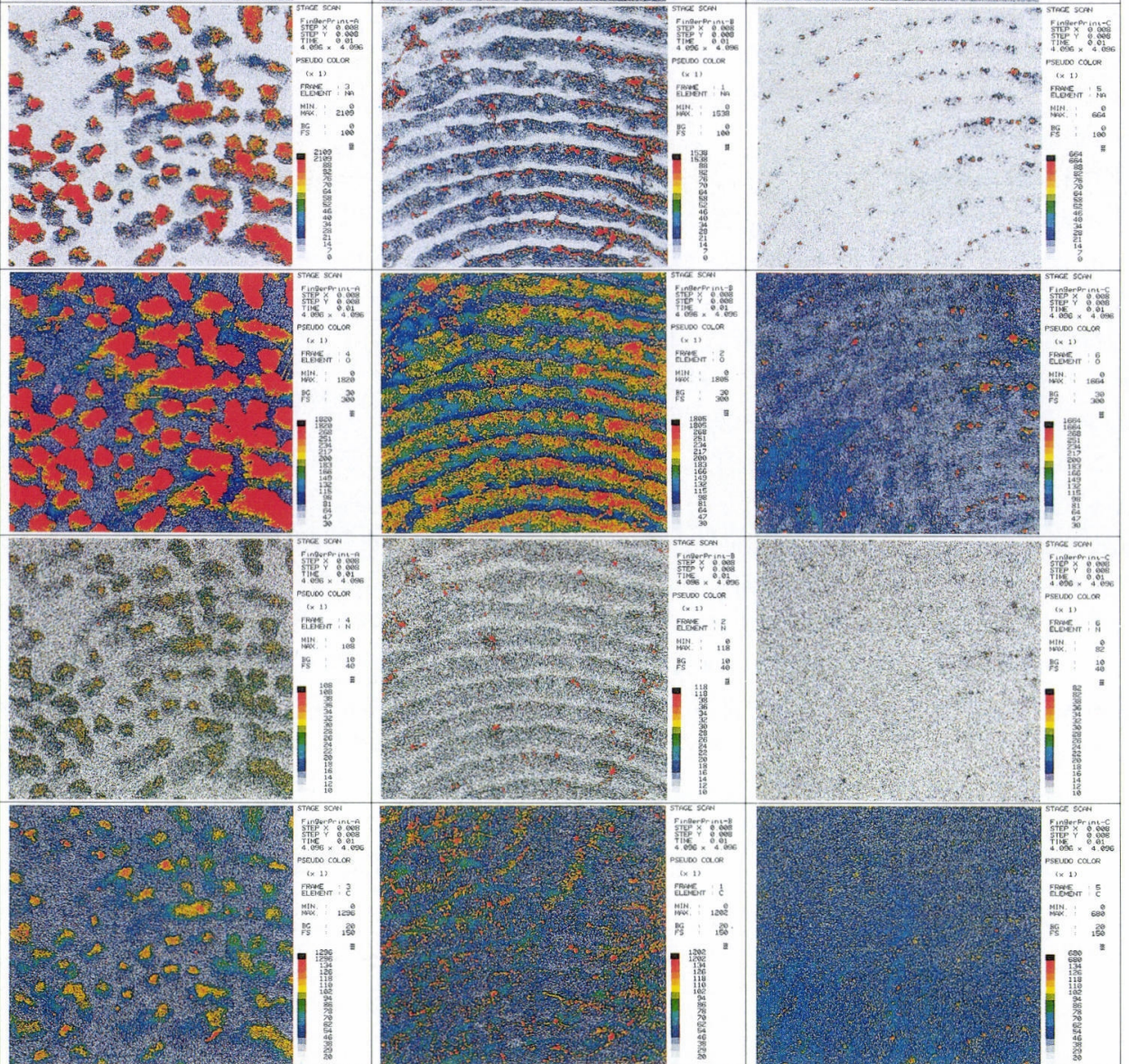

S

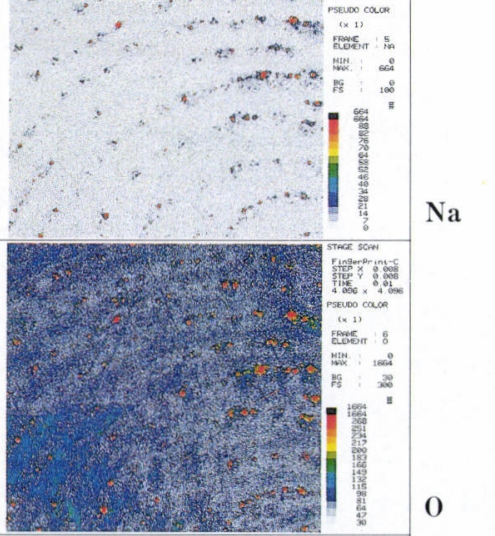

図 3 EPMA による指紋の成分分布(マッピング）。 
向の濃度変化を求めた。試料 A， B, C, (D) について 作成後 12 日間放置してから分析した。Bについてはそ の後さらに 18 日間（つまり作成後 30 日間）放置してか ら再度分析した（試料 $\mathrm{B}^{\prime}$ )。また試料 $\mathrm{E}$ は作成後 16 日 間放置してから分析に供した。分析条件はX線源は $\mathrm{Mg}$ $\mathrm{K} \alpha, 10 \mathrm{kV}, 30 \mathrm{~mA}$, 分析領域は $\mathrm{A} \cdot \mathrm{B} \cdot \mathrm{C}$ が $1 \mathrm{~mm}^{\phi}$, $\mathrm{B}^{\prime}$ と $\mathrm{E}$ が $6 \mathrm{~mm}^{\phi}$ である。エッチングは $\mathrm{A} ・ \mathrm{~B} ・ \mathrm{C}$ 亿対 しては $2 \mathrm{kV}$ で $50 \AA / \mathrm{min}, \mathrm{B}^{\prime}$ と $\mathrm{E}$ 亿対しては $400 \mathrm{~V}$ で $200 \AA / m i n$ である。定性分析の結果を 図 4, 図 6 およ び図 8 に示す。深さ分析 (depth profile) の結果を図

5, 図 7 および図 9 に示す。試料Dは銅板自身の污れ・ 腐食を示しているが, $\mathrm{A} ・ \mathrm{~B} ・ \mathrm{C}$ および $\mathrm{B}^{\prime}$ に存在してい る $\mathrm{C}, \mathrm{O}, \mathrm{Na}$ などは銅板自身のものではなく指紋(手垢)

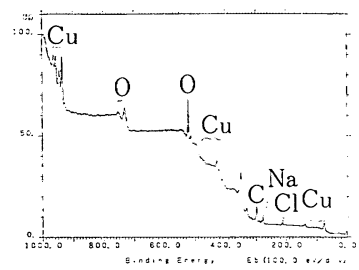

Sample A

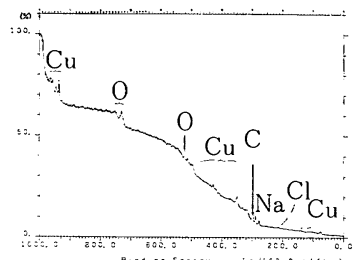

Sample C

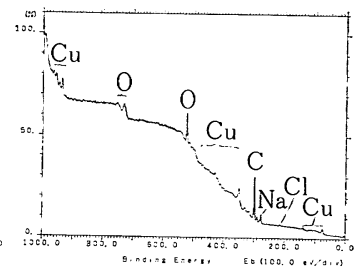

Sample B

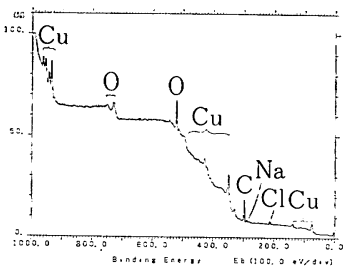

Sample D

図 4 ESCA 亿よる指紋の定性分析。

Sample A
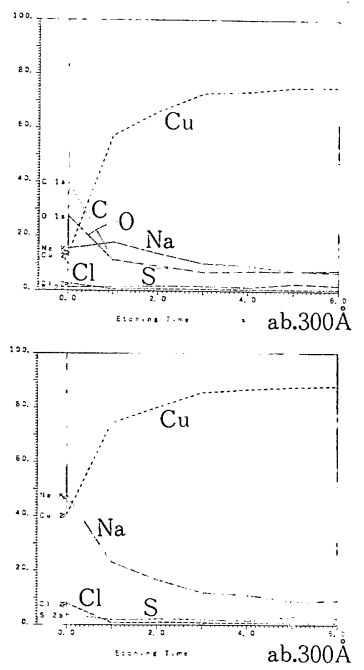

Sample B
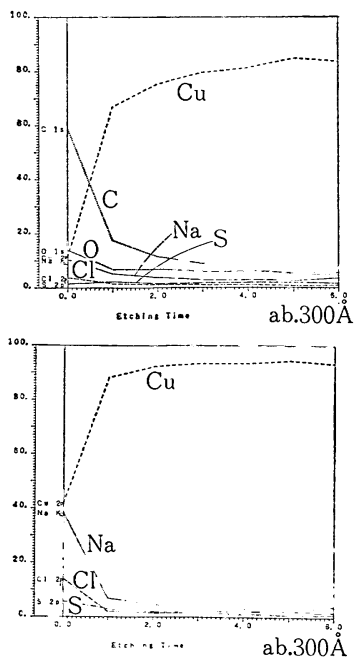

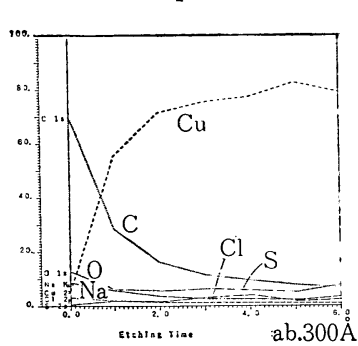

Sample D

図 7 ESCA による指紋の深さ分析。試料 $\mathrm{B}^{\prime}$ (Bの 分析後 2 週間)。

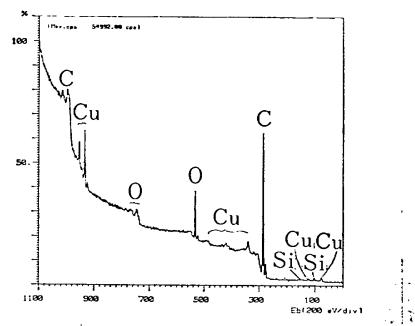

図 $8 \mathrm{ESCA}$ による手垢の定性分析。試料 $\mathrm{E}$ 。

図 6 ESCA による指紋の定性分析。試料 $\mathrm{B}^{\prime}$ (Bの 分析後 2 週間)。
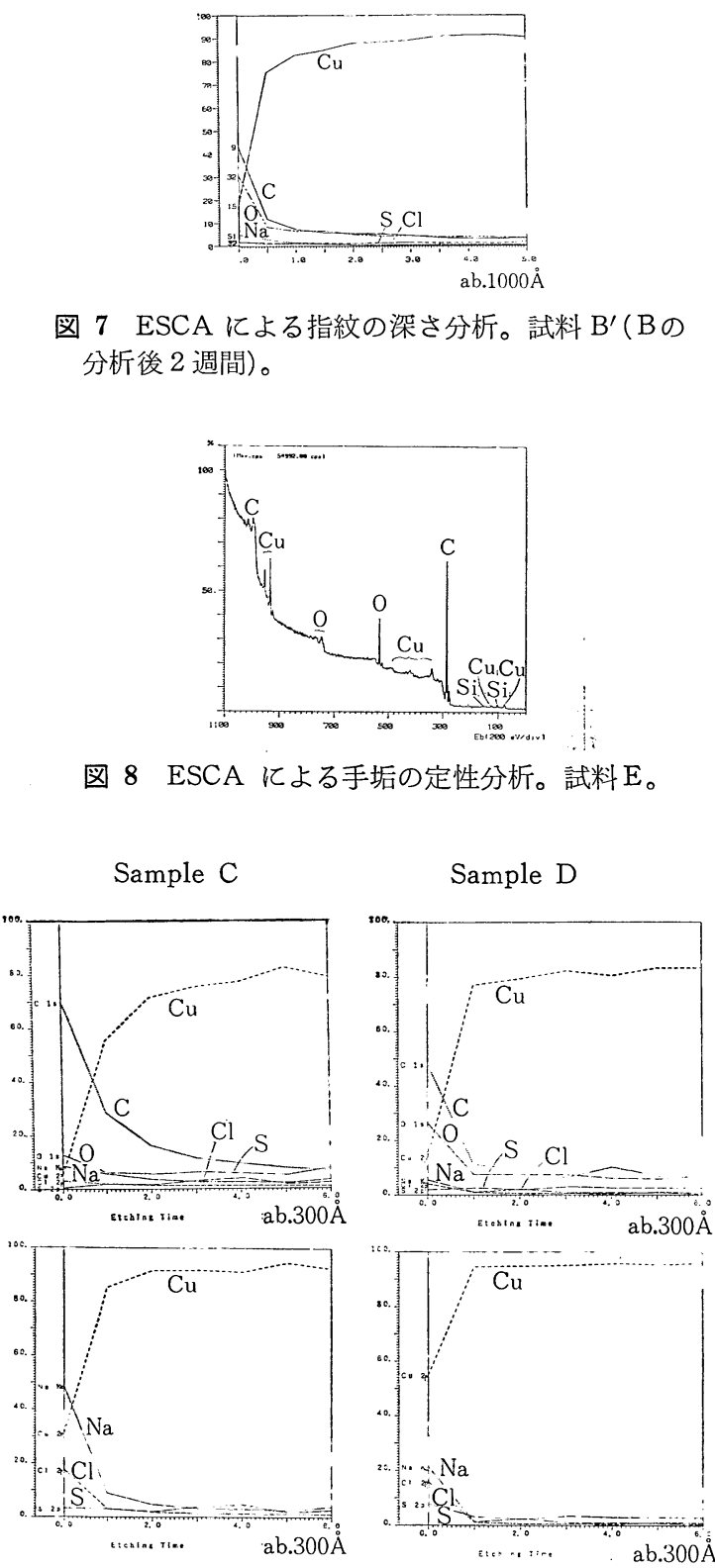

図 5 ESCA による指紋の深さ分析（下列はCとOを除外した濃度比率）。 


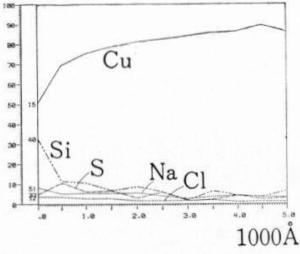

(1)

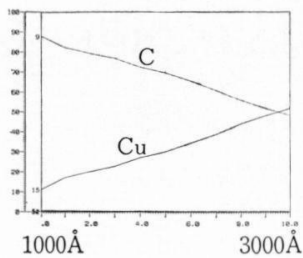

(3)

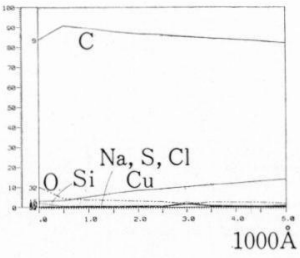

(2)

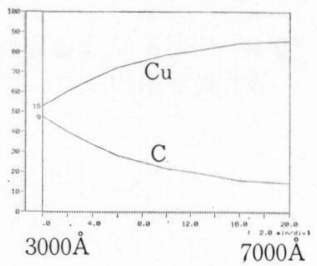

(4)
図 $9 \mathrm{ESCA}$ による手垢の深さ分析。試料 $\mathrm{E}$ 。(1) CとOを除外した濃度比率，（2）Cと○を含む濃 度比率，（3）深部のCと $\mathrm{Cu}$ の分布 $(1000 \AA \rightarrow$ $3000 \AA),(4)$ 深部のC之 $\mathrm{Cu}$ の分布 $(3000 \AA \rightarrow$ $7000 \AA$ )。

の成分である。主なる結果を表 6 にまとめて示す。
甲さんが手を洗う前 (B) と洗った後 (A) で $\mathrm{Na} や$ ○に大きな違いが出ている。乙れはまさしく手垢(指紋) 成分の違いである。甲さんと乙さんの手を洗う前がよく 似ているのも面白い。手洗い後, 時間が経つと, 指の表 面が乾き分泌物が一種の風化を起とし，まわりの污れが 付着しカバーされ, 同じような環境で行動していると同 じような表面状態になるのかもしれない。EPMA で多 量に検出された試料AのKが ESCA ではほんの少しし か検出されなかった。ESCA の感度特性では説明でき ず, Ar スパッタの影響であろうか。Bが放置されると 変化するようである(当然かもしれないが)。B'はBに 比べて Oが増え C， Na などは減っている。このことは Bがすでに 12 日間放置された後なので, 指紋がついた 直後とは変化している可能性を示している。ただ, ここ では経時変化を云々するにはデータ不足である。

丙さんのEはよ゙うなっているのであろうか。とにかく なるたけべタべタに付けたものを作るために, 何度も何 度も額や鼻をとすっては銅板になすりつけた。さらに銅 板の上で指でこねくりまわした。結果は $7000 \AA$ の深さ

表 6 ESCA による分析結果のまとめ。

\begin{tabular}{|c|c|c|c|}
\hline 試料 & 表 面 成 分 & 分 & 考 \\
\hline A & $\mathrm{C}, \mathrm{O}, \mathrm{Na}(\mathrm{Cl}, \mathrm{S})$ & $\begin{array}{l}\mathrm{C}, \mathrm{O}, \mathrm{Na} \text { が } 300 \AA \text { でも存在してい } \\
\text { る }\end{array}$ & $\begin{array}{l}\mathrm{B} \text { より } \mathrm{Na}, \mathrm{O} \text { が多く，特に } \mathrm{Na} \text { が相 } \\
\text { 当量深くまで存在している }\end{array}$ \\
\hline B & $\mathrm{C}, \mathrm{O}, \mathrm{Na}, \mathrm{Cl}(\mathrm{S})$ & $\begin{array}{l}\mathrm{C} \text { が } 300 \AA \text { で存在している。O }, \mathrm{Na} \\
\text { は } 100 \AA \text { 以深では少ない }\end{array}$ & $\begin{array}{l}\text { Aより } \mathrm{C} か ゙ \text { 多く } \mathrm{Na}, \mathrm{O} \text { は少ない。手 } \\
\text { 坧層はAよりは薄い }\end{array}$ \\
\hline $\mathrm{B}^{\prime}$ & $\mathrm{C}, \mathrm{O}, \mathrm{Na}, \quad(\mathrm{Cl}, \mathrm{S})$ & $\mathrm{C}, \mathrm{O}, \mathrm{Na}$ は $100 \AA$ までは存在する & $\begin{array}{l}\mathrm{B} \text { より } \mathrm{C}, \mathrm{Na} \text { が減ってOが増加。 } \mathrm{B} \\
\text { より手垢層が薄くなっている }\end{array}$ \\
\hline $\mathrm{C}$ & $\mathrm{C}, \mathrm{O}, \mathrm{Na}, \mathrm{Cl}(\mathrm{S})$ & $\begin{array}{l}\text { かなりのCが } 200 \AA \text { まで存在。O, } \\
\mathrm{Na} \text { は } 100 \AA \text { 以深は少ない }\end{array}$ & 全体としてBとよく似ている \\
\hline $\mathrm{D}$ & $\mathrm{C}, \mathrm{O}, \mathrm{Na}, \mathrm{Cl} \quad(\mathrm{S})$ & $\begin{array}{l}\text { 表面 } 50 \AA \text { 以下の污れのみ。内部は } \\
\text { キレイ }\end{array}$ & \\
\hline $\mathrm{E}$ & $\mathrm{Si}, \mathrm{Na}, \mathrm{S}, \mathrm{Cl}$ & $\begin{array}{l}\text { Si が } 400 \AA \text { くらいまで存在する。 } \\
\text { Cが } 7000 \AA \text { であまだ存在する }\end{array}$ & $\begin{array}{l}\text { 表面に } \mathrm{Si} \text { がある。 } \mathrm{C} 之 \mathrm{Cu} \text { が連続的 } \\
\text { 浱度変化している理由が疑問 }\end{array}$ \\
\hline
\end{tabular}

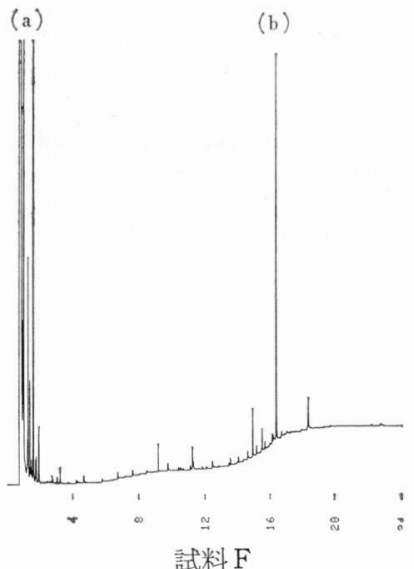

試料 $\mathrm{F}$

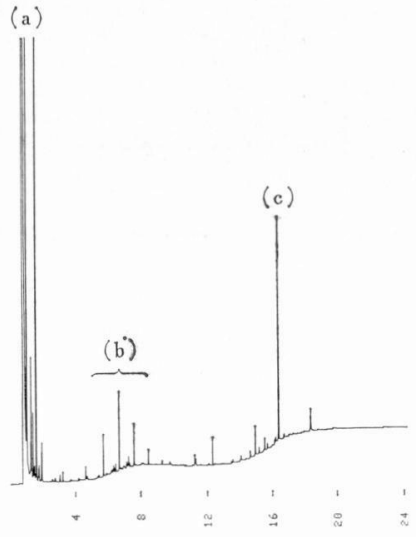

試料 G

図 10 手垢のガスクロマトグラム。（a）アセトン，(b ）整髪料，（c）灯油。 
であまだカーボンがかなりある。このととは単純に手垢 層が厚いと考えたらいいのだが，ならば何故カーボンと 銅の濃度が連続的に変化しているのか。両元素が本当に 共存しているのか（共存の原因は？ 最初からならてん なキレイなカーブにはならない。後からなら元素が移動 したのか…)，それとも極端な斜めエッチングが生じて しまったのか（光学的観察ではそうは見えない)。たい へん気になる結果なので後日次の追試を行なった。

Eについてさらに 13 日後 (作成後 29 日後)，Eと同 様の作成したものについて 1 時間後，石けんを銅板にて すり付けたあのの直後, 真空グリース（シリコーン系） を鋼板になすりつけたあのの直後について，Cと Cu の depth profileを行なった。いずれも図9の（3), (4) と同様の結果であった。どうあネトネトした有機力 ーボンのArエッチングによる depth profile の問題らし く，正確な分析ができていないと判断した。

なお，データを示してはいないが元素の結合状態を見 るために $\mathrm{Cu}$ 等の波形変化も記録して調べてみたとこ ろ，手垢層と銅板の界面あたりでの状態変化は特には認 められていない。あっとも $\mathrm{Cu}$ の波形はオージェピーク あ光電子ピークあ状態変化が顕著ではないので断定的に はいえない。

\subsection{GC による分析}

試料は $500 \mu l$ のアセトンで抽出し, $10 \mu l$ まで濃縮し て分析に供した。分析条件は下記である。

カラム: Fused Silica キャピラリーカラム

Methyl phenyl silicone $0.25 \mathrm{~mm}$ I.D $\times 25 \mathrm{~m}$ カラム温度: $70^{\circ} \mathrm{C}$ ( 1 分) $\rightarrow 300^{\circ} \mathrm{C} 15^{\circ} \mathrm{C} / \mathrm{min}$

$$
\text { インジェクタ:スプリットモード }
$$

検出器: FID

分析結果を図 10 亿示す。デー夕は明解であり, 試料 Fでは整髪料に含まれる比較的沸点の高い基材成分と思 われるピークが現れている。また試料Gでは明らかに灯 油成分のピークが検出されている。

実は FTIR や GCMS での分析データあ欲しかった のであるが, FTIR は試料 ABC について少し試みたも のの試料が薄く, 微量すぎたのか感度不足であった。ま
た GCMS はトライ出来ずじまいであった。FTIR はむ う少し時間をかけて工夫すれば可能かむしれない。多分 試料Eなら比較的簡単かむしれない。いずれにしろ有機 物分析のデータがそしいので非常に心残りのまま一たん 筆を置くことになってしまった。

\section{4.おわりに}

たかが手垢といってはみたあのの, 手垢にすっかりし ゃべらそうとすると各種の薄膜分析・表面分析・微小部 分析, 無機物分析・有機物分析, 極微量分析手法を駆使 しないといけないようである。しかし，現在のとれらの 分析法の能力では十分にしゃべらすととはなかなかたい へんである。まして複数の分析法を 1 つの指紋（手垢） に適用するのには未解决のことが多い（今回の分析は同 様の試料を複数個作成して夫々の装置に分配した)。

そあそあ手垢にしゃべらしてどうしようというのか, 興味本意でやるにはコストあ手間むかかりすぎるようで ある。たった 1 つ残した手垢・指紋からプライベートが あばかれるのは未だ先のととだと安心していいのかす。 なお，本稿を書くにあたって分析を当社応用技術部の 塩見紘一氏, 田辺道穂氏, 荒木 武氏, 藤井岳直氏およ び島津テクノリサーチの柴田恒雄氏に無理をいってお願 いした。ここに深く感謝の意を表わしたい。

\section{文献}

1) 日本生化学会編：“生化学データブック，I”（東 京化学同人, 1979) p. 1536.

2) 日本生化学会編 : “生化学データブック， II”(東 京化学同人, 1980) p. 619.

3）日本生化学会編：“生化学データブック， II”（東 京化学同人, 1980) p. 621.

4）日本生化学会編: “生化学データブック，I”（東 京化学同人, 1979) p. 1573.

以上の他に下記のあのも随時参考にした。

5) 日本化学会編 : “化学便覧, 応用編”(丸善, 1980).

6）松倉豊治編著: “法医学”（永井書店, 1974).

7）日本分析化学会編：“高分子分析ハンドブック” (朝倉書店, 1985).

8）塩川二朗監修: “カークオスマー化学大辞典”（丸 善, 1988). 